\title{
SISTEM ORGANISASI PEMASARAN EKSPOR PADA PT. INDO VENEER UTAMA KARANGANYAR
}

\author{
Muhammad Roestam Afandi \\ Fakultas Ilmu Ekonomi, Universitas Negeri Yogyakarta, Indonesia \\ mroestamafandi@uny.ac.id
}

\begin{abstract}
Abstrak: Sistem Organisasi Pemasaran Ekspor Pada PT. Indo Veneer Utama Karanganyar. Penelitian yang dilakukan bertujuan untuk mengetahui informasi mengenai pembagian tugas atau pengorganisasian yang dijalankan perusahaan dalam melakukan pemasaran ekspor dan mempelajari faktor pendorong maupun penghambat dalam pemasaran ekspor. Teknik analisa yang digunakan dalam penelitian ini merupakan teknik deskriptif kualitatif sedangkan objek penelitian yaitu PT. Indo Veneer Utama Karanganyar. Jenis data yang diperlukan dalam penelitian ini merupkan data lapangan dan data kapustakaan yaitu data yang diperolah langsung dari pihak perusahaan. Hasil penelitian menunjukkan bahwa PT.Indo Veneer Utama Karanganyar menggunakan strategi segmentasi pasar (segmentation), strategi penentuan pasar sasaran (targetting), dan strategi posisi pasar (positioning). Perusahaan juga menggunakan bauran pemasaran (marketing mix) yang terdiri dari 4 unsur yaitu produk (product), harga (price), saluran distribusi (place), dan promosi (promotion) dalam mengembangkan pemasaran ekspor. Faktor-faktor pendorong dalam pemasaran ekspor yang dilakukan PT.Indo Veneer Utama Karanganyar adalah tersedianya pasar mancanegara, optimalisasi laba, jumlah barang produksi tinggi, produk berdaya saing tinggi, tersedianya layanan house trading. Selain faktor pendorong juga ada faktor penghambat yaitu Sumber Daya Manusia yang terbatas, Kuota Impor setiap negar yang berbeda, kurs mata uang yang tidak stabil, dan adanya aturan regional setiap organisasi negara yang berbeda.
\end{abstract}

Kata Kunci: Sistem Organisasi, Pemasaran, Faktor Pendorong, Faktor Penghambat

\begin{abstract}
Export Marketing Organizational Systems at PT.Indo Veneer Utama Karanganyar. The research carried out aims to find out information about the Division of tasks or organization carried out by companies in carrying out export Marketing and studying the driving and inhibiting factors in export marketing. The Analysis technique used in this study is a qualitative descriptive technique while the object of research is PT. Indo Veneer Utama Karanganyar. The type of data needed in this study is field data and library data, which are data obtained directly from the company. The results showed that PT.Indo Veneer Utama Karanganyar used a market segmentation strategy, a target market determination strategy (positioning), and a market positioning strategy (positioning). The company also uses a marketing mix consisting of 4 elements, namely product, price, distribution channel (place), and promotion in developing export marketing. The driving factors in export marketing conducted by PT. Indo Veneer Utama Karanganyar are the availability of foreign markets, optimization of profits, high quantities of manufactured goods, highly competitive products, and availability of house trading services. In addition to the driving factors there are also inhibiting factors, namely limited human resources, import quotas for each country that are different, unstable currency exchange rates, and the existence of regional rules for each different country organization.
\end{abstract}

Keywords: Organizational System, Marketing, Driving Factors, Inhibiting Factors

\section{PENDAHULUAN}

Pemasaran merupakan salah satu kunci keberhasilan dalam penjualan. Pemasaran yang berkualitas tentu lebih memperoleh hasil atau penjualan yang maksimal. Tantangan yang ada di era globalisasi dalam hal pemasaran salah satunya adalah perbedaan karakteristik selera konsumen. Artiya setiap konsumen memiliki standar masing-masing dalam menentukan tingkat kepuasan. Sebagai contoh ketika si A menyebutkan rasa bakso di warung Pak Mamad enak, namun bisa juga si B menyebutkan rasa bakso di warung Pak Mamad tidak enak. Hal ini disebabkan karena selera konsumen dan standar 
yang beragam nilai tingkat kepuasan yang berbeda. Oleh sebab itu, konsumen dapat menggunakan produk yang sama tanpa harus disebabkan oleh kebutuhan atau motif yang sama. Soerang produsen atau pengusaha harus mampu memahami keadaan tersebut dengan istilah segmentasi pasar. Pride and Ferrel (2012) menyebutkan segmentasi pasar adalah suatu proses membagi pasar ke dalam segmensegmen pelanggan potensial dengan kesamaan karakteristik yang menunjukkan adanya kesamaan perilaku pembeli. Segmentasi pasar ini dapat dikatakan suatu proses pengelompokkan konsumen dan penyampaian nilai kepada konsumen dengan tujuan akhir adalah meningkatkan penjualan.

Pemasaran adalah proses yang memiliki tujuan meningkatkan penjualan atau omzet suatu perusahaan. Selain itu proses pemasaran juga memiliki tujuan memuaskan kebutuhan dan keinginan konsumen akan suatu barang dengan selera yang dimilikinya. Menurut Chandra (2002), strategi pemasaran merupakan rencana yang menjabarkan ekspektasi perusahaan akan dampak dari berbagai aktivitas atau program pemasaran terhadap permintaan produk atau lini produknya di pasar sasaran tertentu. Program pemasaran meliputi tindakan-tindakan pemasaran yang dapat mempengaruhi permintaan terhadap produk, diantaranya dalam hal mengubah harga, memodifikasi kampanye iklan, merancang promosi khusus, menentukan pilihan saluran distribusi, dan sebagainya. Philip Kotler (1994) mendefinisikan pemasaran adalah suatu proses dan manajerial dimana individu dan kelompok mendapatkan kebutuhan dan keinginan mereka dengan menciptakan, menawarkan, dan bertukar produk yang bernilai satu sama lain. Oleh karena itu posisi pemasaran sangat penting dan perlu mendapat perhatian lebih dari perusahaan demi mencapai tujuan peningkatan laba perusahaan.

Keefektifan sangat diperlukan untuk memperoleh strategi pemasaran yang tepat, sehingga perlu adanya cara terbaik supaya yang sudah dibentuk atau direncanakan perusahaan jauh-jauh hari sebelumnya tidak sia-sia. Ekspor Impor merupakan salah satu kegiatan yang didongkrak pemerintah guna meningkatkan perekonomian suatu negara. Kegiatan ekspor maupun impor sebenarnya sangat mudah dilakukan bagi mereka yang mau berusaha namun, kegiatan ekspor impor bisa terasa sangat sulit bagi mereka yang tidak mau aktif untuk memulaimya. Ekspor impor pada dasarnya adalah sama dengan kegiatan jual beli pada umumnya hanya saja ekspor dan impor melibatkan jarak sedangkan jual beli domestik tidak mempertimbangkan faktor jarak.

Menurut Marolop Tandjung (2011), pengertian ekspor adalah pengeluaran barang dari daerah pabeanan Indonesia untuk dikirim ke luar negeri dengan mengikuti ketentuan yang berlaku terutama mengenai peraturan kepabeanan. Pada dasarnya kegiatan ekspor dilandasi atas kesadaran bahwa setiap negara di dunia ini tidak ada yang benar-benar bisa mandiri dan saling membutuhkan satu sama lainnya. Suatu negara melakukan ekspor produksinya ke negara lain yang membutuhkan produk tertentu dan tidak dapat memenuhi kebutuhan akan barang tersebut. Jauh sebelum terjadinya ekspor tentu akan diawali beberapa proses mulai dari pengenalan produk atau promosi produk, ketertarikan 
atas produk, tawar-menawar, kontrak dagang sampai akhirnya terjadi transaksi jual beli. Pihak yang menjual komoditi disebut eksportir sedangkan pihak yang membeli disebut importir.

Dalam memenfaatkan peluang yang ada, perusahaan perlu mengenali kekuatan apa yang dimilikinya sehingga mampu terus bersaing dalam pasar global. Selain kekuatan, perusahaan juga harus mampu menganalisa kelemahan apa yang dimilikinya untuk dapat meminimalisisr atau bahkan menghindari hambatan yang akan muncul dari kelemahan tersebut. Tujuan pemasaran yang paling efektif salah satunya adalah perusahaan mencari posisi terbaik dalam melakukan pemasaran. Di dalam melakukan pemasaran, perusahaan harus fleksibel artinya tidak kaku dengan aturan yang sebelumnya diterapkan perusahaan, tetapi harus lebih dinamis mengikuti apa yang ada di lapangan mulai dari permasalahan sampai kepada hambatan-hambatan yang dutemui di lapangan dan harus segera dalam penyelesaiaannya. Hal ini dikarenakan bukan jaman dimana produsen memaksakan kehendak kepada konsumen tetapi sebaliknya saat ini yang ada adalah konsumen memaksakan kehendak kepada produsen.

PT Indo Veneer Utama adalah satu diantara perusahaan yang bergerak pada bidang furniture yang terletak di Colomadu, Karanganyar. PT Indo Veneer Utama memproduksi dan menjual bermacam-macam produk furniture, produk yang diproduksi terbagi dalam dua line yaitu garden furniture dan solid door furniture. Dalam menghadapi persaingan, tentu saja tidak semulus seperti yang direncanakan, namun perusahaan harus selalu peka terhadap tantangan yang ada demi meningkatkan kualitas serta memberikan pelayanan terbaik bagi prousen. Meskipun sudah melakukan beberapa kali penjualan terhadap pihak asing, tantangan dan hambatan akan selalu hadir seiring dengan perkembangan jaman terbukti dengan tidak selalu lancar dalam sistem ekspor yang dilakukan. Berikut beberapa buyer yang telah melakukan transaksi dengan PT.Indo Veneer Utama dan kuantitas yang diambil :

Tabel 1. Data Penjualan Furniture 5 Tahun Terakhir

\begin{tabular}{|l|r|r|r|r|r|}
\hline \multirow{2}{*}{ Buyer } & \multicolumn{6}{|c|}{ Tahun } \\
\cline { 2 - 6 } & $2010($ Set) & $2011($ Set) & $2012($ Set) & $2013($ Set) & 2014 (Set) \\
\hline S2dio (AUS) & 178 & 290 & 175 & 310 & 300 \\
\hline Sunshine Coast (SNG) & 168 & 310 & 175 & 488 & 655 \\
\hline Loganholme (AUS) & 155 & 423 & 231 & 233 & 181 \\
\hline Jindalee (THAI) & 168 & 190 & 100 & 228 & 273 \\
\hline Gautzsch (GMN) & 216 & 187 & 231 & 233 & 189 \\
\hline Fyshwick (GMN) & 92 & 190 & 125 & 228 & 531 \\
\hline Nunawading (SNG) & 216 & 187 & 620 & 226 & 197 \\
\hline Castle Hill (AUS) & 92 & 193 & 357 & 225 & 802 \\
\hline Master Bacth (AUS) & 525 & 193 & 240 & 170 & 240 \\
\hline WarnersBay (AUS) & 277 & 130 & 137 & 260 & 176 \\
\hline Jumlah & 2087 & 2293 & 2391 & 2601 & 3544 \\
\hline
\end{tabular}


Tabel diatas menunjukkan dari tahun 2010 sampai dengan tahun 2014 selalu terjadi kenaikan tingkat penjualan produk furniture pada PT.Indo Veneer Utama. Kenaikan tigkat penjualan ini tidak terlepas dari efektifnya strategi pemasaran yang dijalankan pihak perusahaan sehingga sangat menarik untuk dikaji sebagai bahan penelitian. Di tahun 2010 perusahaan mampu menjual sejumlah 2087set, pada tahun 2011 penjualan furniture mencapai 2293set, setelah itu pada tahun 2012 penjualan mencapai 2391set, pada tahun 2013 2601set furniture yang terjual dan pada tahun 2014 mampu malakukan penjualan sebesar 3544set furniture. Meskipun penjualan sudah dapat dikatakan baik, perusahaan tentu ingin mempertahankan kelangsungan usahanya, PT. Indo Veneer Utama mengupayakan beberapa strategi yang paling efektif untuk menarik buyer-buyer lain dari beberapa negara untuk meningkatkan penjualan. Pemasaran yang dilakukan diharapkan tidak hanya lokal, namun diharapkan strategi pemasaran ekspor. PT Indo Veneer Utama diharapkan mampu melakukan inovasi dalam melakukan pemasaran baik dalam maupun luar negeri, namun dalam dunia bisnis tentu saja akan muncul berbagai resiko-resiko dalam menjaga hubungan baik dan komunikasi dengan pembeli.

Berdasarkan data dan uraian diatas, kajian ini ingin mengetahui strategi pemasaran yang dilakukan oleh PT. Indo Veneer Utama. Selain itu, penulis juga ingin megetahui apa saja tahap yang dilakukan dalam pemasaran tersebut. Oleh karena itu, penulis tertarik mengangkat permasalahan yang ada dengan judul "Sistem Organisasi Pemasaran Ekspor Pada PT. Indo Veneer Utama”.

\section{METODE}

\section{Tahap dan Prosedur Analisis Data}

a. Proses pengumpulan data

Proses pengumpulan data terbagi menjadi dua bagian, yaitu pengumpulan data internal dan pengumpulan data eksternal. Proses atau tahapan ini dilakukan dengan tujuan untuk memperoleh informasi yang dibutuhkan dalam penelitian. Proses pengumpulan data dilakukan dengan cara wawancara dengan pihak perusahaan dan dari file yang diperoleh dari staff perusahaan.

b. Proses analisis data

Proses analisis data merupakan suatu proses untuk mengolah data menjadi informasi supaya karakteristik data tersebut mudah dipahamidan bermanfaat dalam proses penelitian. Tahap analisis dilakukan setelah pengumpulan seluruh informasi yang berpengaruh terhadap kelangsungan perusahaan, tahap selanjutnya adalah memanfaatkan semua informasi tersebut dalam model-model kuantitatif perumusan strategi pemasaran. Deskriptif analisis bertujuan untuk melukiskan suatu objek tertentu. 


\section{Teknik Analisis Data}

Teknik analisis data adalah suatu langkah yang sangat menentukan dari suatu penelitian, karena analisis data berfungsi untuk menyimpulkan hasil penelitian. Tahapan teknik analisis data adalah sebagai berikut:

a. Menyusun usulan penelitian yang dimulai dari penelitian pendahuluan.

b. Pengolahan data hasil wawancara dan berbagai informasi lapangan yang di peroleh dari perusahaan.

c. Melakukan pengecekan terhadap data hasil wawancara yang dilakukan terhadap narasumber dan melakukan perbandingan data yang diperoleh dengan berbagai informasi yang terkait. Pengolahan data dianggap optimal apabila data yang diperoleh lengkap dan dapat mewakili permasalahan yang akan menjadi objek penelitian.

\section{PEMBAHASAN}

\section{A. PEMASARAN PRODUK FURNITURE PADA PT. INDO VENEER UTAMA} KARANGANYAR

PT. Indo Veneer Utama Karanganyar menggunakan rumusan strategi pemasaran yang berawal dari strategi segmentasi pasar (segmentation), strategi penentuan pasar sasaran (targetting), dan strategi posisi pasar (positioning). Selain itu, perusahaan mengembangkan bauran pemasaran (marketing mix) dalam mengembangkan strategi pemasaran yang terdiri dari 4 unsur yaitu produk (product), harga (price), saluran distribusi (place), dan promosi (promotion). Berikut uraian tentang strategi pemasaran produk furniture PT. Indo Veneer Utama Karanganyar:

1. Pelaksanaan strategi segmentasi pasar (segmentation)

Menetapkan segmentasi pasar merupakana langkah pertama yang dilakukan PT. Indo Veneer Utama Karanganyar. Dalam melakukan segmentasi pasar, perusahaan fokus terhadap beberapa calon buyer dengan kebutuhan furniture dengan kuantitas yang besar. Adapun kriteria yang dibutuhkan dalam melakukan segmentasi pasar antara lain sebagai berikut :

a. Strategi segmentasi geografis

Pihak perusahaan tidak menjadikan masalah berarti dalam melakukan strategi segmentasi geografis. Hal ini dikarenakan segmentasi berdasarkan geografis merupakan strategi pemasaran penetapan letak calon buyer potensial. Perusahaan tidak merasa terdapat kendala bagi pihak perusahaan karena memang tidak ada pengkhususan yang ditetapkan dari segi letak calon buyer dari PT.Indo Veneer Utama Karanganyar.

b. Strategi segmentasi demografis 
Secara demografis dilihat dari segi usia tidak ada kiteria khusus untuk menjadi segmentasi hal yang lebih dikhususkan adalah dari segi keuangan calon buyer seperti pihak perusahaan lebih mengutamakan membidik calon buyer dengan keuangan menengah keatas daripada buyer dengan keuangan menengah hal ini dapat dilihat dari ketertarikan produk yang perusahaan tawarkan.

c. Strategi segmentasi perilaku

Dalam menjalankan strategi segmentasi perilaku tidak ada perlakuan khusus, namun pihak perusahaan lebih menekankan pada resiko dalam melakukan kerja sama dengan calon buyer. Hal ini dimaksudkan untuk memudahkan pihak perusahaan dalam proses administrasi.

2. Strategi Penentuan Pasar Sasaran (Targetting)

Penentuan pasar sasaran menjadi hal utama dalam bagian ini karena hal ini akan berpengaruh dalam tingkat penjualan produk yang ditawarkan. PT. Indo Veneer Utama Karanganyar menentukan pasar sabagai bidikan diutamakan instansi, pelaku bisnis perumahan, kontraktor, pengembang apartemen, perhotelan dll. Hal ini dirasa lebih efektif dikarenakan perkiraan jumlah pesanan dengan kuantitas yang lebih banyak dibandingkan buyer perseorangan.

3. Strategi Posisi Pasar (Position)

PT. Indo Veneer Utama Karanganyar merupakan solusi terbaik dalam kebutuhan produk furniture baik outdorr furniture maupun indoor furniture. Dengan mengedepankan kualitas maka dipastikan produk yang dihasilkan dapat berssaing dengan perusahaan yang memproduksi produk yang sama dan masuk ke dalam pasar yang sama pula dengan PT.Indo Veneer Utama Karanganyar. Sebagai pembanding, PT. Indo Veneer Utama Karanganyar menjual dengan harga yang lebih murah dengan kualitas yang sama dibandingkan perusahaan lain. Sunlonger yang menjadi salah satu produk andalan harga yang ditetapkan selisih antara Rp 1.000.000,00 - Rp 2.000.000,00 dengan harga dari perusahaan lain. Dengan posisi seperti ini tentu diharapkan PT. Indo Veneer Utama Karanganyar lebih unggul dalam menawarkan produk yang dihasilkan.

4. Bauran Pemasaran (Marketing Mix)

Bauran pemasaran atau dikenal dengan istilah marketing mix sangat diperlukan guna mencapai target pasar yang telah ditetapkan perusahaan. Metode yang digunakan perusahaan dalam bauran pemasaran dengan menganalisa produk, harga, tempat, promosi disebut dengan 4P (product, price, place, promotion). Keempat metode analisis yang digunakan dapat dijelaskan sebagai berikut: 


\section{a. Analisa Produk}

Produk yang dihasilkan PT. Indo Veneer Utama Karanganyar baik itu berupa barang maupun jasa adalah sebagai berikut:

a) Produk Furniture Baik itu Indoor Furniture maupun Outdoor Furniture

PT. Indo Veneer Utama Karanganyar merupakan perusahan yang melayani pembuatan berbagai jenis furniture. Jenis produk yang terdapat pada PT. Indo Veneer Utama dbedakan menjadi 2 yaitu:

\section{i. Indoor Furniture}

Produk indoor furniture yaitu produk yang biasa digunakan di dalam ruangan seperti meja, kursi, tempat tidur. Produk ini menggunakan jenis kayu meranti karena digunakan di dalam ruangan sehingga tingkat perawatan yang tidak begitu rumit karena tidak terkena sinar matahari maupun air secara langsung.

ii. Outdoor Furniture

Produk ini dikatakan Outdoor Furniture karena digunakan untuk luar ruangan. Produk yang masuk dalam kategori ini adalah kursi taman, sett meja kursi santai, pembatas bagian taman, pagar taman, dll. Produk ini menggunakan bahan kayu merbau maupun jati karena diluar ruangan sehingga tingkat penyusutan semakin tinggi oleh karena itu dipilih kayu dengan kualitas lebih dibandingkan dengan produk Indoor FurnitureBerikut contoh barang yang diproduksi PT. Indo Veneer Utama Karanganyar :

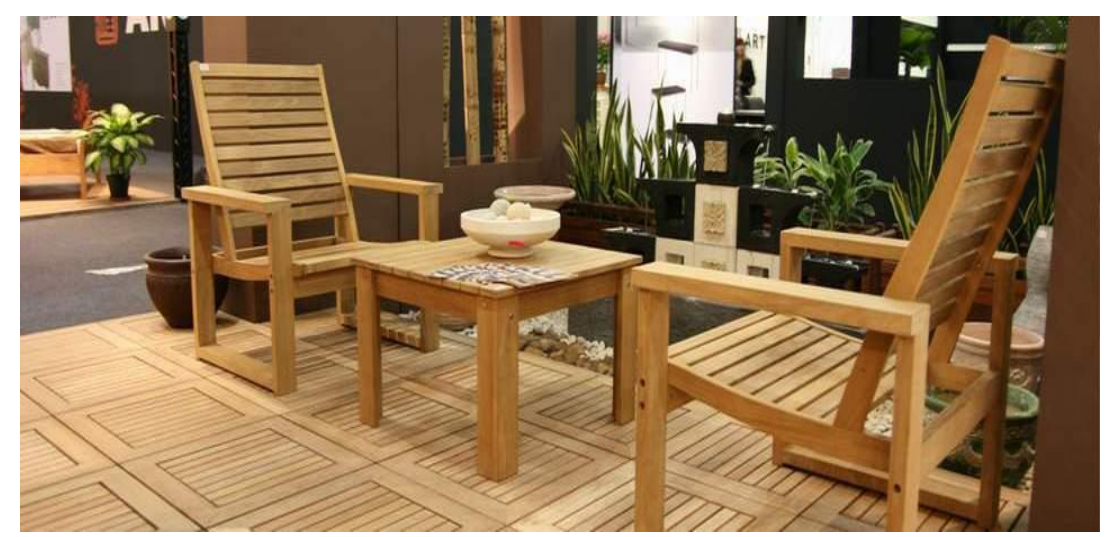

Gambar 1. Kursi Taman

Sumber: $w$ ww.indoveneer.com

b) Jasa Penggergajian Kayu

PT. Indo Veneer Utama Karanganyar selain melayani pembuatan produk furniture juga melayani jasa penggergajian kayu baik dari ukuran besar ataupun kecil dengan 
ketentuan tertentu. Pengerjaan jasa ini juga dilakukan pada bagian produksi menjadi satu dengan bagian produksi barang mentah. Pada dasarnya tidak ada perbedaan spesifik dari produk ini dengan perusahaan lainnya karena produk akhir juga tergantung permintaan konsumen sari segi ukuran dan lainnya.

\section{b. Analisis Harga (Price)}

Harga memegang peran sangat penting dalam pemasaran karena salah satu langkah sosialisasi akan produk yang dijual selalu mencantumkan harga. Teologi murah dalam benak calon buyer kadang memang menjadi sedikit kendala bagi pihak perusahaan. Tidak jarang pula calon buyer mengininkan harga rendah dengan kualitas yang tinggi. Hal ini membuat pihak perusahaan berputar otak untuk tidak kalah dengan perusahaan lain yang menawarkan produk yang sama. Proses penetapan harga yang dilakukan oleh PT Indo Veneer Utama Karanganyar adalah dengan metode cost plus mark up yaitu dengan cara menjumlahkan semua komponen yang digunakan seperti pengadaan bahan baku, biaya produksi, biaya tenaga kerja, sampai dengan forwarding ditambahkan dengan prosentase yang diinginkan. Berikut beberapa contoh harga produk yang dihasilkan.

Tabel. 2. Daftar Harga Produk Furniture

\begin{tabular}{|c|c|}
\hline Jenis Produk (Outdoor/Indoor) & $\begin{array}{c}\text { Harga } \\
\end{array}$ \\
\hline Pintu (balcony) & Rp 2.000.000- Rp 3.500.000,00 \\
\hline Meja (Table) & Rp 10.000.000- Rp 15.000.000,00 \\
\hline Bangku(Bench) & Rp 1.500.000- Rp 2.000.000,00 \\
\hline $\operatorname{Dipan}($ Daybed $)$ & $\mathrm{Rp} 4.000 .000-\mathrm{Rp} 12.000 .000,00$ \\
\hline Kursi Malas(Sunlonger) & Rp 2.000.000- Rp 5.000.000,00 \\
\hline Kursi(Chair) & $\operatorname{Rp} 1.500 .000-\operatorname{Rp} 2.500 .000,00$ \\
\hline
\end{tabular}

Sumber:PT Indo Veneer Utama Karanganyar

\section{c. Analisis Tempat (Place)}

PT Indo Veneer Utama beralamat di Jl.LU Adisucipto no.1 PO BOX 229 ColomaduKaranganyar. Dengan didukung lokasi yang strategis dan sangat luas memudahkan pihak perusahaan dalam menjalankan usahanya yang meliput bongkar muat barang yang secara umum tentu membutuhkan tempat yang luas. PT Indo Veneer Utama Karanganyar yang didukung dari segi letak yaitu tepat di pinggir jalan besar bukan kota juga memudahkan akses truk-truk besar yang akan menuju ke PT Indo Veneer Utama.

\section{d. Analisa Promosi (Promotion)}

Beberapa langkah promosi yang dilakukan PT Indo Veneer Utama Karanganyar yaitu:

- Periklanan 
Iklan merupakan suatu komunikasi tidak langsung yang menggambarkan dan menyampaikan informasi yang menjadi keunggulan dari PT.Indo Veneer Utama Karanganyar yang tersusun dalam kata-kata. Tujuan dari iklan yang dilakukan adalah mencari perhatian calon buyer sehingga akan datang dan melakukan transaksi jualbeli. Cara periklanan produk pada PT Indo Veneer Utama Karanganyar adalah dengan cara membuat katalog produk yang disediakan guna melakukan personal selling. Selain itu pihak perusahaan juga membuat website sebagai bentuk promosi. Berikut contoh laman yang terdapat dalam website perusahaan sebagai salah satu bentuk promosi:

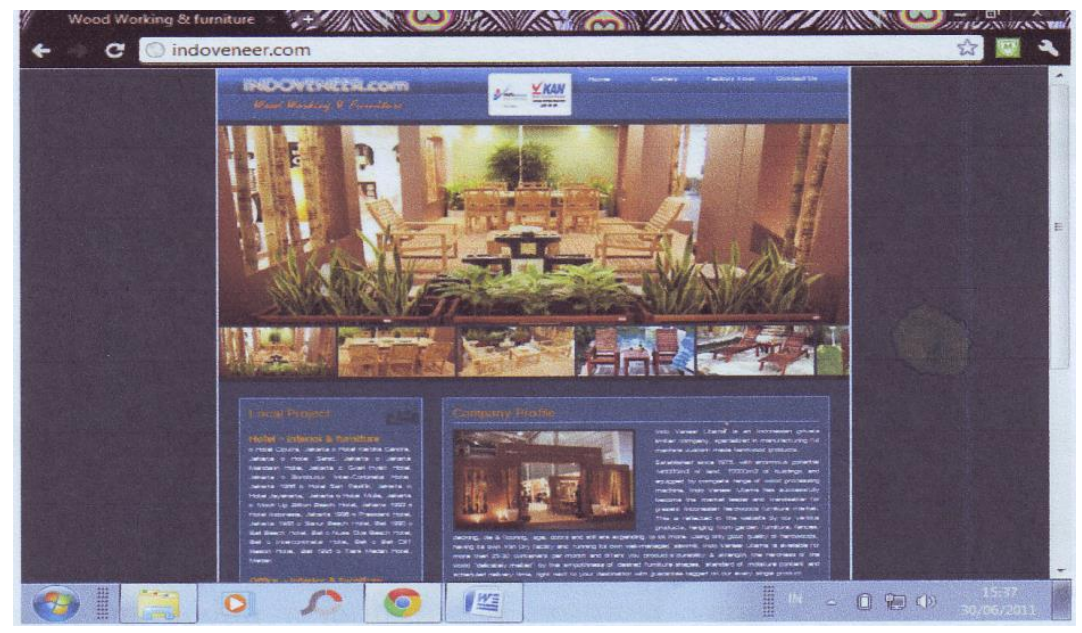

Gambar 2. Laman website

Sumber:www.indoveneer.com

Website yang telah dibuat didalamnya berisi tentang semua informasi yang ada kaitannya dengan perusahaan mulai dari sejarah berdirinya, lokasi perusahaan, produk yang dihasilkan, kualitas produk, dll. Pada website juga terdapat layanan yang langsung tersambungkan dengan bagian $R \& D$ ataupun bagian logistik yang akan selalu online pada jam kerja. Selain itu, untuk daftar harga yang diinginkan buyer juga langsung bisa mengakses melalui kotak pesan yang ada dengan cara mencamtumkan alamat email. Pihak perusahaan akan langsung membalas tentang informasi yang dibutuhkan ke email yang telah dilampirkan. Berikut laman kontak person perusahaan atau kontak untuk memperoleh informasi yang diharapkan: 


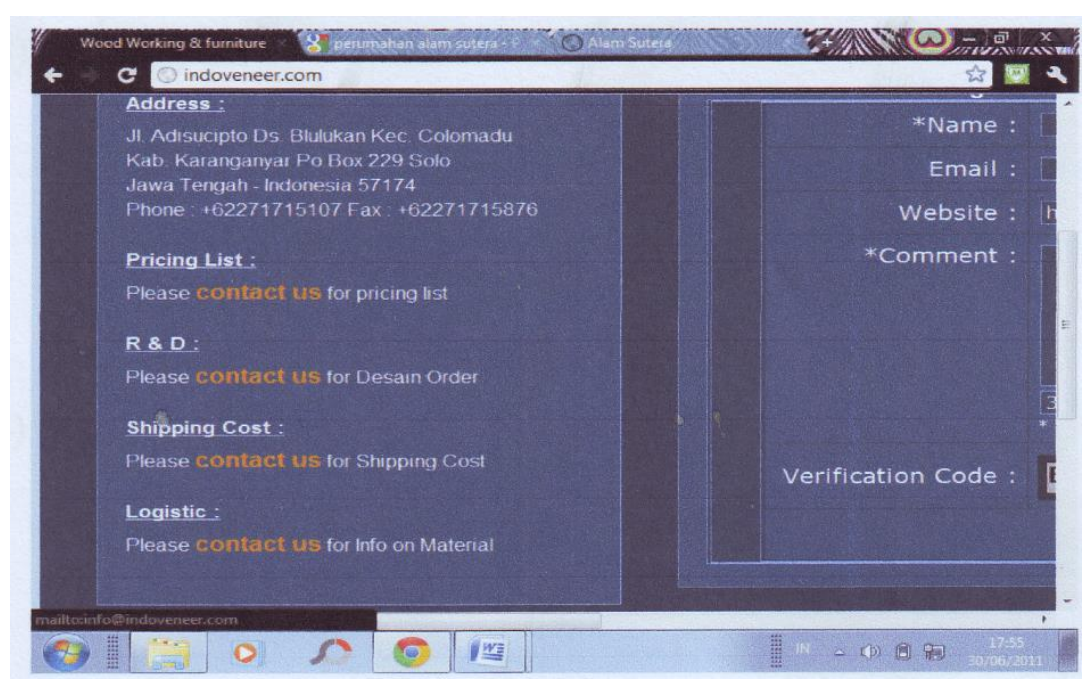

Gambar 3. Tampilan sambungan pihak perusahaan

Sumber:www.indoveneer.com

- Promosi Penjualan/Sales Promotion

PT Indo Veneer Utama melakukan promosi penjualan dengan cara mengikuti permintaan buyer, biasanya dengan cara pengiriman sample terlebih dahulu kepada buyer. Sample yang dikirimkan harus sesuai dengan permintaan buyer. Biasanya dengan kesepakatan-kesepakatan di muka terlebih dahulu. Sebagai contoh kesepakatan atas biaya sample tersebut. Seandainya buyer tidak setuju dengan sample yang dibuat, maka biaya akan ditanggung oleh buyer dan sample harus dibeli. Namun jika memang buyer memberikan kesempatan lagi untuk memperbaikinya, maka dengan kesepakatan biaya kirim sample kedua ditanggung oleh kedua belah pihak. Kejadian seperti ini memang biasanya terjadi berulang-ulang sampai terjdi kesepakatan ekspor-impor. Kejadian ini juga biasanya dilakukan dengan buyer yang sudah mengenal dengan pihak perusahaan.

- Pameran Dagang

Pameran dagang dapat dikatakan sangat efektif dalam melakukan promosi penjualan. Hal ini dikarenakan dengan seringnya mengikuti pameran dagang maka calon buyer akan lebih mengenal dan lebih tahu tentang produk-produk yang dihasilkan. Dalam melaksanakan pameran dagang, PT. Indo Veneer Utama Karanganyar terfokus pada kegiatan yang dilakukan di Mall dan acara-acara festival tahunan seperti Jakarta Fair. Pameran dagang yang dilaksanakan akan berjalan dengan baik ketika ditunjang dengan teknologi dan persiapan yang maksimal. Teknologi yang digunakan bertujuan untuk meyakinkan calon buyer akan kualitas perusahaan. Selain itu, PT Indo Veneer 
Utama juga melakukan kerja sama dengan buyer Suncoast Sitra Pte Ltd Singapore yang diadakan sekali setiap tahunnya di Singapore. Dengan pameran dagang semacam ini perusahaan mengenalkan barang produksi kepada buyer di luar negeri karena dalam acara ini diundang beberapa calon buyer dari beberap negara. Tidak menutup kemungkinan juga datang beberapa broker yang tidak diundang karena informasi adanya acara ini sangatlah luas.

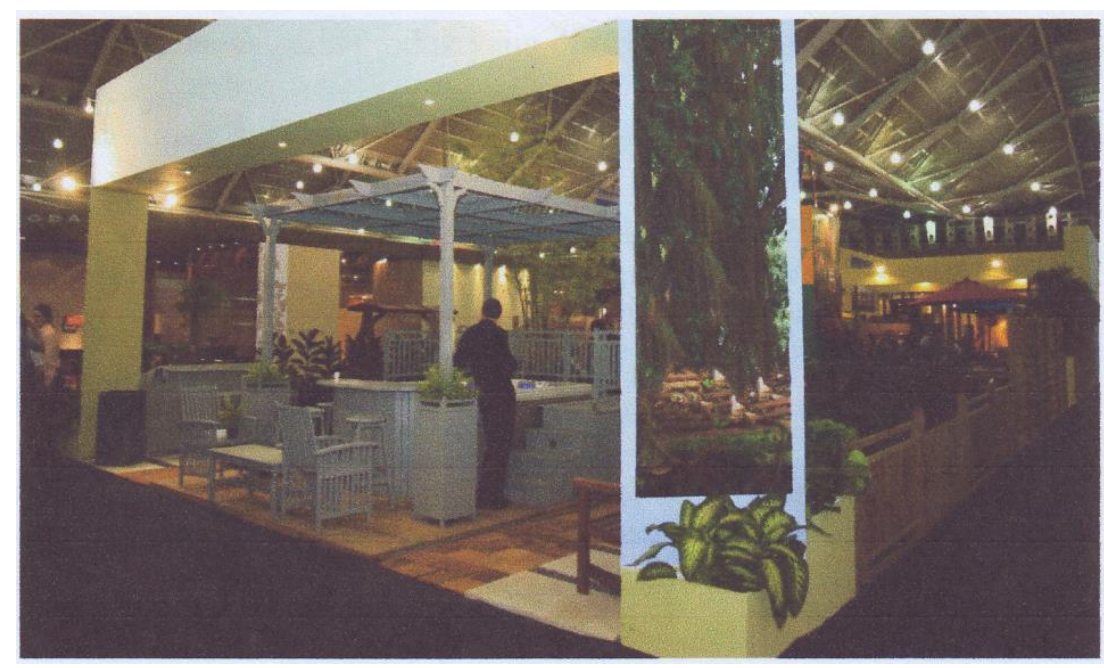

Gambar 4. Stan Pameran Dagang

Sumber:www.indoveneer.com

Dalam hal ini, kedudukan PT indo Veneer Utama merupakan pihak kedua. Sudah menjadi kesepakatan antara PT Indo Veneer Utama bersama Suncoast Sitra Pte Ltd bahwa dalam pameran dagang ini dengan mengatasnamakan Suncoast Sitra Pte Ltd. Sistem yang berjalan sesuai kesepakatan awal adalah seandainya ada buyer yang masuk tetap berhubungan dengan pihak Suncoast Sitra Pte Ltd selanjutnya pihak Suncoast Sitra Pte Ltd menghubungi PT Indo Veneer Utama dalam pengadaan barangnya

\section{B. FAKTOR PENDORONG DAN PENGHAMBAT DALAM PROSES PEMASARAN PADA} PT.INDO VENEER UTAMA KARANGANYAR

Faktor pendorong merupakan faktor yang dapat menunjukkan bahwa perusahaan mampu melakukan ekspor produk ke beberapa negara tertentu. Dalam hal ini, PT Indo Veneer Karanganyar sebagai pelaku ekspor melihat terdapat beberapa faktor yang membuat perusahaan terdorong untuk melakukan kegiatan ekspor. Beberapa hal yang membuat PT. Indo Veneer Utama Karanganyar terdorong dalam melakukan ekspor adalah: 
1. Optimalisasi Laba

Semua perusahaann tentu mempunyai tujuan sama yaitu memperoleh hasil yang maksimal. Hal ini membuat PT Indo Veneer Karanganyar membuat keputusan untuk melakukan perdagangan luar negeri dengan tujuan yang sama pula. Berikut data perbandingan dari PT Indo Veneer Utama Karanganyar sebelum dan sesudah melakukan ekspor:

Tabel 3. Kenaikan Pendapatan Sebelum Ekspor

\begin{tabular}{|c|c|}
\hline Tahun & Penghasilan \\
\hline 1995 & Kurang Lebih Rp 550.000.000,00 \\
\hline 1996 & Kurang Lebih Rp 670.000.000,00 \\
\hline 1997 & Kurang Lebih Rp 740.000.000,00 \\
\hline 1998 & Kurang Lebih Rp 880.000.000,00 \\
\hline 1999 & Kurang Lebih Rp 950.000.000,00 \\
\hline Rata-Rata Kenaikan & $17.3 \%$ \\
\hline
\end{tabular}

Sumber:PT.Indo Veneer Utama Karanganyar, Data Diolah

Tabel 4. Kenaikan Pendapatan Setelah Ekspor

\begin{tabular}{|c|c|}
\hline Tahun & Penghasilan \\
\hline 2000 & Kurang Lebih Rp 1.600.000.000,00 \\
\hline 2001 & Kurang Lebih Rp 1.850.000.000,00 \\
\hline 2002 & Kurang Lebih Rp 2.500.000.000,00 \\
\hline 2003 & Kurang Lebih Rp 3.150.000.000,00 \\
\hline 2004 & Kurang Lebih Rp 3.750.000.000,00 \\
\hline Rata-Rata Kenaikan & $23.9 \%$ \\
\hline
\end{tabular}

Sumber:PT.Indo Veneer Utama Karanganyar, Data Diolah

Dapat dilihat bahwa dari data diatas diperolah kenaikan persentase laba terdapat perbedaan yang cukup besar antara kondisi perusahaan sebelum dan sesudah ekspor. Dalam kurun waktu 5 tahun data yang diperoleh pada saat sebelum ekspor menunjukkan angka persentase kenaikan 17,3\% sedangkan rata-rata persentase setelah ekspor menunjukkan angka 23,9\%. Hal ini menunjukkan bahwa dengan ekspor maka laba perusahaan akan meningkat sehingga apa yang menjadi tujuan perusahaan tercapai. 


\section{Tersedianya Pasar Manca Negara}

PT Indo Veneer Utama Karanganyar merupakan perusahaan bidang furniture yang sudah mempunyai pangsa pasar domestik cukup kuat. Dengan keadaan seperti ini tentu memungkinkan pihak perusahaan untuk melakukan diversifikasi pasar dengan tujuan mencapai pasar yang lebih luas mengingat persaingan dalam dunia usaha semakin ketat baik itu di pasar domestik maupun manca negara. Sebagai perusahaan yang berkembang cukup baik setidaknya PT Indo Veneer Utama Karanganyar sudah mempunyai beberapa buyer tetap yaitu: Suncoast Sitra Pte Ltd Singapore, Javadoor Ltd British Virgin Island, S2dio Pty Ltd Australia, Taste Furniture Australia. Ketersediaan pasar di luar negeri menjadi daya tarik bagi PT. Indo Veneer Utama Karanganyar. Dengan melihat kondisi yang seperti ini tentu pihak perusahaan semakin bersemangat dalam mengembangkan pasar ekspor sehingga keuntungan perusahaan akan meningkat.

\section{Jumlah Barang Produksi Tinggi}

PT. Indo Veneer Utama Karanganyar memperkerjakan 258 tenaga pria dan 142 tenaga wanita. Selain itu pihak perusahaan juga sudah memiliki kebun tanam legal sendiri sehingga antara kebutuhan akan barang baku produksi dengan tenaga kerja seimbang hal tentu akan membuat kapasitas produksi yang tinggi, maka dari itu perusahaan mengambil keputusan untuk ekspor karena perusahaan tentu akan merugi apabila barang produksi tidak segera terjual. Pasar domestik yang awalnya menjadi segmentasi utama tentu juga memiliki keterbatasann kebutuhan akan furniture terlebih lagi pelaku pasar domestik semakin meningkat sesuai perkembangan jaman. Hal ini semakin mendorng pihak PT Indo Veneer Utama Karanganyar tergerak untuk melakukan ekspor.

\section{Produk Berdaya Saing Tinggi}

PT Indo Veneer Utama Karanganyar menggunakan bahan baku kayu dari hasil tanam sendiri yang tentunya dengan kualitas daya saing tinggi terlebih perusahaan mempunyai kebun tanam legal tersendiri. Beberapa kayu yang digunakan dalam proses produksi sangat diminati pasar asing terbukti dengan semakin berkembangnya pasar. Menurut hasil wawancara dengan bagian produksi yaitu Bapak Suharyoko, beberapa bahan baku yang digunakan PT. Indo Veneer Utama Karanganyar adalah kayu jati, kayu merbau, kayu meranti merah, kayu kelapa. Melihat dari beberapa bahan yang telah disebutkan tentu dapat diketahui bahwa produk yang dihasilkan perusahaan merupakan produk berdaya saing cukup tinggi. Selain dilihat dari bahan baku tentu juga mempertimbangkan aspek model maupun proses finishing karena hal ini sangat berpengaruh terhadap hasil akhir produk yang nantinya akan diekspor. Selain 
menggunakan barang baku yang telahdisebutkan, PT. Indo Veneer Utama Karanganyar juga menerima pesanan dengan bahan baku permintaan dari pelanggan.

\section{Tersedianya Layanan Trading House}

Trading House atau disebut juga wisma dagang merupakan konsep dari pemerintah yang bertujuan untuk mempermudah eksportir melakukan penetrasi pasar internasional dengan begitu tentu akan lebih cepat dalam menemukan calon pembeli. PT. Indo Veneer Utama Karanganyar tentu tidak akan menyia-nyiakan kesempatan ini. Dengan pastilayanan ini digunakan sebaik mungkin sampai pada akhirnya menemukan calon pembeli dan melakukan transaksi.

Bebarapa faktor pendorong diatas yang membuat PT. Indo Veneer Utama Karanganyar melakukan ekspor. Selain terdapat faktor pendorong, juga terdapat faktor penghambat perusahaan dalam melakukan ekspor, meski penghambat ini bisa teratasi, namun hal ini sangat mengganggu proses terjadinya ekspor apabila tidak terdapat penanganan serius dari pihak perusahaan. Berikut merupakan faktor penghambat ekspor bagi PT. Indo Veneer Utama Karanganyar:

1. Kulitas Sumber Daya Manusia yang Terbatas

Masih kurangnya tenaga ahli ekspor menjadi salah satu penghambat ekspor di PT. Indo Veneer Utama Karanganyar. Produk yang baik tanpa didasari kualitas pemasaran yang handal pula hasilnya juga tidak akan memuaskan bagi perusahan. Hal ini tidak $100 \%$ terjadi pada PT. Indo Veneer Utama Karanganyar namun ada saja yang menghambat unsur pelaksanaan ekspor. Salah satu kendala yang terjadi adalah dalam bahasa. Penggunaan bahasa yang tidak selalu sama menjadi salah satu penghambat. Komunikasi menjadi hal yang panting dalam pengenalan produk dalam harapannya nanti produk bisa terjual. Segmentasi pasar PT. Indo Veneer Utama Karanganyar Selain negara-negara Eropa maupun Australia juga negaranegara Timur Tengah yang tentu memiliki bahasa yang berbeda. Hal ini membuat perusahaan terhambat dalam menawarkan produk karena ahli bahasa yang disiapkan hanyalah ahli Bahasa Inggris yang pada dasarnya adalah bahasa Internasional. Hal ini terjadi pada tahun 1996 saat PT. Indo Veneer Utama memperoleh pembeli dari Timur Tengah dimana calon pembeli menghendaki kursi taman. Karena yang dipesan adalah barang sett maka yang harus dijelaskan memang sedikit banyak oleh karena itu, mengingat pihak perusahaan tidak mempunyai kompetensi dalam bahasa Timur Tengah maka terpaksa menyewa seorang penerjemah kilat yang tentu saja bayarannya tidak murah karena penerjemh tersebut tidak masuk dalam bagian dari perusahaan atau karyawan perusahaan.

2. Kuota Impor Antar Negara yang Berbeda 
Peraturan impor suatu negara tidak terlepas dari kebijakan yang telah diterapkan oleh pemerintah negara tersebut. Memang ada negara yang menetapkan kuota impor berdasarkan kebutuhan negaranya, ada pula yang menerapkan peraturan tersebut untuk kepentingan lain. Bagi PT. Indo Veneer Utama Karanganyar yang menjadi permasalahan adalah apabila negara yang dituju merupakan negara degan penetapan kuota atas dasar kepentingan lain. Misalkan suatu negara membutuhkan meja kursi 1000 sett, namun pemerintah hanya memperbolehkan mengimpor 500 sett dengan tujuan pengoptimalan sumber daya yang ada di negaranya. Hal ini menjadi masalah bagi PT. Indo Veneer Utama Karanganyar karena sudah jelas terlihat ada pasar di negara tersebut namun tidak boleh masuk karena terbentur oleh aturan yang ada tersebut. Hal ini juga berdampak negatif bagi PT. Indo Veneer Utama Karanganyar karena kurang bisa mengoptimalkan laba dari negara yang menjadi tujuan ekspor.

3. Kurs Mata Uang Asing yang Tidak Stabil

Tidak stabilnya kurs mata uang asing membuat pihak perusahaan selaku eksportir kesultian dalam menentukan harga valuta asing yang berdampak pada tingkat permintaan dan penawaran dalam suatu perdagangan. Menurut pengalaman dari pihak PT. Indo Veneer Utama yang pernah terjadi adalah ketika terjadi deal penjualan terhadap salah satu buyer Australia rupiah masih dalam keadaan Rp 10.450,00 namun akibat ketidakstabilan kurs mata uang yang signifikan terjadi pelemahan nilai rupiah ke Rp 12.100,00 dengan rentang waktu yang tidak begitu lama. Hal ini tentu merugikan pihak perusahaan terlebih terjadi keteledoran dari pihak perusahaan dalam butir-butir mperjanjian jual beli pada saat itu.

\section{Adanya Organisasi Regional Antar Negara}

Dalam suatu regional terdapat suatu organisasi ekonomi yang bertujuan untuk memajukan perekonomian negara anggotanya. Dalam lingkup organisasinya, perkumpulan negara-negara yang tergabung akan mengeluarkan peraturan khusus terkait ekspor dan impor untuk negara anggota. Oleh karena itu negara lain yang tidak termasuk dalam organisasinya tentu akan sulit menembus pasar yang telah tersedia. PT. Indo Veneer Utama Karanganyar mengalami hal ini ketika akan memasuki pasar Kuwait. Pihak perusahaan melihat terdapat peluang besar untuk produk yang ditawarkan yaitu indoor furniture. Namun dalam praktek yang terjadi Kuwait masuk dalam orgaisasi negara-negara eksportir Timur Tengah sehingga peraturan belum memperbolehkan pasar furnitur untuk Kuwait dimasuki negara lain yang bukan anggota. 


\section{KESIMPULAN}

Dari penelitian ini diperoleh kesimpulan bahwa strategi yang dilakukan PT.Indo Veneer Utama Karanganyar dalam melakukan pemasaran ekspor sudah sesuai yang diharapkan meskipun terdapat sedikit permasalahan atau hambatan dipasar internasional namun hal ini tidak menyurutkan penjualan ekspor PT. Indo Veneer Utama Kranganyar. Strategi pemasaran dengan menerapkan langkah pemasaran sejauh perusahaan ini beroperasi belum menemukan permasalahan yang berarti. Namun untuk semakin menunjang tercapainya harapan yang lebih dalam hal ini keuntungan tentu harus dilakukan perbaikan dari segala sisi. Dari uraian diatas dapat disimpulkan bahwa PT Indo Veneer Utama Karanganyar menggunakan beberapa langkah strategi yaitu:

1. Strategi Segmentasi Pasar (Segmentation)

Strategi ini merupakan langkah awal PT Indo Veneer Utama Karanganyar dalam melakukan pemasaran. Segmentasi ini difokuskan kepada calon buyer potensial yang mempunyai kebutuhan produk furniture dengan skala besar. Untuk memudahkan dibagi menjadi 3 sudut pandang yaitu dari segmentasi geografis, demografis, dan perilaku.

2. Strategi Penentuan Pasar Sasaran (Targetting)

Penentuan pasar sasaran menjadi hal utama dalam bagian ini karena hal ini akan berpengaruh dalam tingkat penjualan produk yang ditawarkan. PT. Indo Veneer Utama Karanganyar menentukan pasar sabagai bidikan diutamakan instansi, pelaku bisnis perumahan, kontraktor, pengembang apartemen, perhotelan dll.

3. Strategi Posisi Pasar (Position)

Posisi pasar dari PT Indo Veneer Utama Karanganyar dapat dilihat dari beberapa aspek yang telah dijelaskan sebelumnya termasuk dari segi segmentasi pasar dan harga dari produk yang dijual. Dengan hal itu tentunya para konsumen sudah mengetahui posisi dari PT Indo Veneer Utama Karanganyar merupakan eksportir yang mampu bersaing dengan perusahaan lainnya.

4. Bauran Pemasaran (Marketing Mix)

PT Indo Veneer Utama Karanganyar juga menggunakan bauran pemasaran atau marketing mix dalam menjalankan strategi pemasarannya. Bauran pemasaran meliputi :

a. Produk

Produk yang dihasilkan berupa indoor furniture dan outdoor furniture yang merupakan produk unggulan dari PT Indo Veneer Utama Karanganyar. Indoor furniture merupakan produk yang digunakan dalam ruangan, sedangkan outdoor furniture merupakan produk yang digunakan di luar ruangan. Selain produk, PT Indo Veneer Utama Karanganyar juga menerima penggergajian kayu. 
b. Harga

Harga yang ditetapkan pihak perusahaan sudah merupakan harga pasar untuk tujuan negara tertentu. Penetapan harga berdasarkan metode cost plus mark up yaitu dengan menjumlahkan beberapa elemen dalam produksi ditambahkan dengan laba atau keuntungan yang diinginkan pihak perusahaan. Selain itu PT Indo Veneer Utama Karanganyar juga memberikan diskon khusus pada buyer tertentu untuk menjaga supaya tetap berlangganan.

c. Tempat (Place)

Letak dari PT Indo Veneer Utama Karanganyar yang memadai dari beberapa aspek tentu memudahkan untuk melakukan kegiatan perdagangan mulai dari pendistribusian barang baku sampai ke pengiriman barang produksi.

d. Promosi

Pelaksanaa strategi promosi berjalan sudah cukup baik. Hal ini dibuktikan dengan terus bertambahnya buyer yang didapat baik itu dari pemasaran website, pameran, ataupun personal selling.Sebelum melaksanan ekspor tentu saja terdapat alasan yang dapat mendorong perusahaan untuk mengambil keputusan tersebut. Beberapa hal yang mendorong PT Indo Veneer Utama dalam melaksanakan pemasaran ekspor yaitu :

1) Optimalisasi laba

2) Tersedianya pasar manca negara

3) Jumlah barang produksi tinggi

4) Produk berdaya saing tinggi

5) Tersedianya layanan house trading

Selain faktor pendorong, tentunya juga timbul faktor penghambat dalam melakukan ekspor baik itu muncul dari dalam maupun luar perusahaan. Beberapa faktor penghambat yang ditemui PT Indo Veneer Utama Karanganyar dalam melakukan ekspor adalah:

1) Kulitas Sumber Daya Manusia yang Terbatas

2) Kuota Impor Antar Negara yang Berbeda

3) Tidak Stabilnya Kurs Mata Uang Asing

4) Adanya Organisasi Regional Antar Negara

\section{DAFTAR PUSTAKA}

Chandra, Gregorius. 2002. Strategi dan Program Pemasaran. Edisi 1. Andi. Yogyakarta

Kotler, Philip \& Gary Amstrong. 1994. Dasar-Dasar Pemasaran: Principles Of Marketing 7C. Jakarta: Prenhalindo

Pride dan Ferrel. 2012. Marketing Principles Edisi Terjemahan. Jakarta: Erlangga 
Tandjung, Marolop. 2011. Aspek dan Prosedur Ekspor-Impor. Jakarta: Salemba Empat.

\section{UCAPAN TERIMA KASIH}

Artikel ini merupakan hasil dari penelitian yang telah dilakukan. Penulisan artikel ini tidak akan pernah terwujud tanpa bantuan dari berbagai pihak. Ucapan terima kasih kepada pihak-pihak yang telah berkontribusi pada semua proses pelaksanaan penelitian dan penerbitan artikel ini.

\section{PROFIL PENULIS}

Muhammad Roestam Afandi lahir di Klaten 25 Januari 1992. Penulis meraih gelar Magister dalam bidang Ekonomi Pembangunan di Universitas Gadjah Mada Yogyakarta pada tahun 2018. Pendidikan Sarjana diselesaikan pada tahun 2015 di jurusan Ekonomi Pembangunan Universitas Sebelas Maret Surakarta. Dalam kesehariannya, penulis mengabdikan diri sebagai dosen Pendidikan Ekonomi Fakultas Ekonomi di Universitas Negeri Yogyakarta. Penulis juga aktif dalam kegiatan penulisan, penelitian dan seminar baik dalam maupun luar negeri. 